DOI: http://doi.org/10.21009/JKKP.081.09

\title{
FENOMENA NOMOPHOBIA PADA ANAK USIA DINI BERDASARKAN TIPOLOGI WILAYAH DAN HUBUNGANNYA TERHADAP PERILAKU PROSOSIAL DAN ANTISOSIAL
}

\author{
Dian Novita ${ }^{{ }^{*}}$, Kenty Martiastuti ${ }^{2}$ \\ ${ }^{1}$ Universitas Terbuka, Tangerang Selatan, Indonesia \\ 2 Badan Akreditasi Nasional PAUD PNF Provinsi Jawa Barat, Bandung Barat 40391, \\ Indonesia \\ *) E-mail: d.novita@ut.ac.id
}

\begin{abstract}
Abstrak
Penelitian ini bertujuan untuk mengidentifikasi fenomena nomophobia pada anak usia dini di wilayah perdesaan dan perkotaan, menganalisis perbedaan perilaku nomophobia dan perilaku sosial antara kedua wilayah, serta menganalisis hubungan perilaku nomophobia terhadap perilaku sosial. Penelitian ini dilakukan di dua wilayah yaitu di Kabupaten Kuningan (representatif wilayah perdesaan) dan Kota Depok (representatif wilayah perkotaan) dengan responden masing-masing sebanyak 50 orang, sehingga total responden adalah 100 orang. Data yang dikumpulkan dari penelitian ini adalah perilaku nomophobia yang menggunakan instrumen NMP-Q (Yildirim,2015) dan perilaku sosial diukur berdasarkan dimensi yang dikembangkan oleh Hurlock (1978) yang terdiri atas perilaku prososial dan antisosial. Melalui uji independent sample t-test, hasil penelitian menunjukkan tidak ada perbedaan signifikan pada perilaku nomophobia antara wilayah perdesaan dan perkotaan. Skor rata-rata perilaku nomophobia di perdesaan adalah 35,61 sedangkan di perkotaan adalah 35,72 yang termasuk kategori rendah. Perilaku sosial di kedua wilayah sebagian besar menunjukkan kategori tinggi (64\%) dan tidak ada perbedaan perilaku sosial secara umum baik di perdesaan maupun perkotaan. Hasil uji korelasi menunjukkan tidak adanya hubungan signifikan antara perilaku nomophobia dan perilaku sosial namun koefisien korelasi negatif yaitu - 0,085 menjadi indikasi bahwa semakin tinggi perilaku nomophobia maka akan semakin rendah perilaku sosial anak usia dini. Hal ini perlu mendapat perhatian bersama, mengingat dampak buruk yang dapat ditimbulkan dari adanya fenomena nomophobia terutama pada anak usia dini.
\end{abstract}

Kata Kunci: anak usia dini, nomophobia, perilaku sosial

\section{Nomophobia Phenomenons in Early Childhood based on Regional Typology and Its Relationship to Prosocial and Antisocial Behaviors}

\begin{abstract}
This study aims to identify the phenomenon of nomophobia in early childhood in rural and urban areas, to analyze differences in nomophobic behavior and social behavior between the two regions and to analyze the relationship between nomophobic behavior and social behavior. This research was conducted in two areas, namely Kuningan District (rural area representative) and Depok City (urban area representative) with 50 respondents each, so that the total number of respondents was 100 people. The data collected from this study were nomophobic behavior using the NMP-Q instrument (Yildirim, 2015) and social behavior was measured based on the dimensions developed by Hurlock (1978) which consisted of prosocial and antisocial behavior. Through the independent samples t-test, it was found that the results of the study showed no significant difference in nomophobic behavior between rural and urban areas. The average score of nomophobic behavior in rural areas is 35,61 , while in urban areas it is 35,72 which is in the low category. Most of the social behavior in the two regions shows the high category (64\%) and there is no difference in social behavior in general, both in rural and urban areas. The results of the correlation test showed that there was no significant relationship between nomophobic behavior and social behavior, but the negative correlation coefficient, namely $-0,085$, is an indication that the higher the nomophobic behavior, the lower the social behavior of early childhood. This needs
\end{abstract}


mutual attention, considering the bad effects that can be caused by the phenomenon of nomophobia, especially in early childhood.

Keywords : early childhood, nomophobia, social behavior

\section{PENDAHULUAN}

Suatu hal yang tidak dapat dipungkiri dan dihindari pada saat ini adalah laju teknologi yang semakin pesat dan melesat bahkan dalam durasi yang begitu singkat. Salah satu bentuk hasil teknologi yang melesat itu adalah gadget (smartphone) yang begitu mudah ditemui di pasaran. Bahkan dengan harga yang relatif murah, "dunia" sudah dalam genggaman kita. Semua kalangan, baik di perkotaan maupun perdesaan dan pada semua golongan usia, baik tua maupun muda, dapat memiliki dan sekaligus mengakses konten apapun yang ada di gadget yang mereka miliki. Sedemikian besar pengaruh gadget ini baik terhadap fisik individu pengguna, maupun terhadap aspek lain seperti psikologis, mental, dan sosial, membuat kita harus waspada terhadap bahaya laten dari perkembangan teknologi ini.

Nomophobia merupakan sebuah gejala dimana individu tidak bisa jauh dari mobile phone dan merupakan suatu penyakit ketergantungan yang dialami seorang individu terhadap mobile phone, sehingga bisa mendatangkan kekhawatiran dan kecemasan yang berlebihan jika tidak ada mobile phone di dekatnya. Orang yang didiagnosis menderita Nomophobia akan lebih banyak menghabiskan waktu dengan mobile phone-nya dibandingkan berinteraksi dengan orang-orang di sekitarnya (Kendler dalam Davidson, dkk., 2006).

Mereka yang menderita nomophobia ditandai dengan perilaku kecemasan yang berlebihan seperti, tidak mampu menon-aktifkan ponselnya untuk beberapa waktu, rasa khawatir yang berlebihan jika kehabisan daya baterai, terus-menerus memeriksa pesan, panggilan, email baru dan jejaring sosial. Bahkan penderita nomophobia dapat membawa ponselnya hingga ke kamar mandi karena terlalu cemas.

Berdasarkan penelitian yang dilakukan oleh Rideout diketahui bahwa terjadi peningkatan penggunaan gadget pada anak yaitu 38 persen di tahun 2011 dan meningkat menjadi 72 persen di tahun 2013. Salah satu faktor yang mendasari meningkatnya persentase anak prasekolah yang menggunakan gadget yaitu karena semakin berkembangnya teknologi, terutama dengan sistem touch screen yang membuat siapapun lebih mudah untuk menggunakannya, bahkan anak usia dini yang belum bisa membaca sekalipun. Tujuan penelitian ini adalah untuk menganalisis fenomena nomophobia di wilayah perdesaan dan perkotaan serta hubungannya dengan perilaku sosial anak usia dini.

\section{METODE}

Pada penelitian ini, responden yang diambil adalah 50 orang tua anak yang berusia 4 6 tahun dari setiap wilayah, sehingga total responden adalah 100 orang. Untuk wilayah kota Depok dipilih secara purposive kelurahan Pondok Petir, sedangkan untuk wilayah Kabupaten Kuningan dipilih secara purposive Desa Jagara Waktu pengambilan data akan dilakukan pada bulan Agustus - Oktober 2020.

Jenis data yang dikumpulkan adalah: (1) Karakteristik Keluarga (pendidikan orang tua dan pekerjaan orang tua; (2) karakteristik contoh (usia dan jenis kelamin); (3) perilaku nomophobia (4) perilaku prososial dan antisosial.

Perilaku nomophobia diukur dengan menggunakan instrument yang dikembangkan berdasarkan Yildirim (2015) yaitu NMP-Q (Nomophobia Questionnaire) yang terdiri atas 4 dimensi (1) perasaan tidak bisa berkomunikasi; (2) kehilangan konektivitas; (3) tidak mampu mengakses informasi dan (4) menyerah pada kenyamanan, dengan total item pertanyaan sejumlah 20. Perilaku sosial mengacu pada dimensi yang dikembangkan oleh Hurlock (1978) 
yaitu perilaku prososial dan antisosial dengan jumlah 38 item pertanyaan. Uji reliabilitas menggunakan cronbach alpha menunjukkan bahwa reliabilitas instrument NMP-Q adalah 0.951, sedangkan instrument perilaku sosial adalah 0.739 .

Data yang telah diperoleh akan diuji secara statistic menggunakan SPSS 23.0 untuk melihat: (1) klasifikasi fenomena nomophobia pada anak usia dini; (2) perbedaan nomophobia di perkotaan dan perdesaan; (3) perbedaan nomophobia berdasarkan jenis kelamin; (4) perbedaan perilaku sosial di perkotaan dan perdesaan; (5) perbedaan perilaku sosial berdasarkan jenis kelamin; (6) hubungan nomophobia dan perilaku sosial anak usia dini autoritatif karena sebagian besar (lebih dari 95 persen) populasi yang ada. Untuk melihat hubungan antar variabel digunakan uji Pearson Correlation dan untuk melihat perbedaan variabel berdasarkan jenis kelamin anak digunakan uji beda Independent T-test.

\section{HASIL DAN PEMBAHASAN}

\section{A. Karakteristik Responden}

Jumlah keseluruhan responden adalah 100 orang yaitu ibu yang memiliki anak usia dini (4-6 tahun). Jumlah responden berdasarkan jenis kelamin anak adalah 54 orang (ibu dari anak laki-laki) dan 46 orang (ibu dari anak perempuan). Selanjutnya, penyebutan laki-laki dan perempuan adalah untuk menggambarkan jenis kelamin anak yang dimiliki oleh responden.

Tabel 1. Sebaran responden berdasarkan jenis kelamin

\begin{tabular}{llll}
\hline \multirow{2}{*}{ Wilayah } & \multicolumn{2}{l}{ Jenis Kelamin } & Jumlah \\
\cline { 2 - 4 } & Laki-laki & Perempuan & \\
\hline Kab Kuningan & 26 & 24 & 50 \\
Kota Depok & 28 & 22 & 50 \\
Jumlah & 54 & 46 & 100 \\
\hline
\end{tabular}

\section{B. Karakteristik Keluarga Responden}

\section{Pendidikan Orang Tua}

Pendidikan merupakan salah satu aspek penting dalam menunjang kualitas sumber daya manusia. Tingkat pendidikan yang dicapai seseorang akan mempengaruhi dan membentuk pola, cara dan pemahaman. Oleh karena itu, secara langsung maupun tidak langsung, tingkat pendidikan akan menentukan baik buruknya pola komunikasi antara anggota keluarga (Gunarsa \& Gunarsa, 1995).

Latar belakang pendidikan orang tua jug berpengaruh terhadap kontrol yang diberikan oleh orang tua kepada anaknya. Seperti hasil penelitian Irmayanti (2018) bahwa kontrol orang tua terutama dari kontrol yang diberikan oleh seorang ibu. Seorang ibu yang memiliki pendidikan tinggi akan menemukan cara-cara yang menarik untuk menjaga anaknya supaya tidak bermain gadget dan untuk ibu yang memiliki pendidikan rendah, sulit menemukan caracara menarik supaya anaknya tidak bermain gadget. Ketidakmampuan orang tua untuk mengawasi anaknya yang sedang bermain gadget, tentu akan memberikan kesempatan kepada anak untuk melihat konten-konten negative yang berupa kekerasan atau pornografi.

Pendidikan merupakan hal terpenting dalam kehidupan kita. Tingkat pendidikan orang tua juga akan menentukan pola yang diterapkannya dalam mengasuh dan mendidik anakanaknya dalam keluarga. Dalam penelitian ini ditemukan bahwa sebagian besar ayah di wilayah penelitian Kabupaten Kuningan (representatif wilayah perdesaan) berpendidikan 
SLTA yaitu sebanyak 36.0 persen. Ada sebanyak 8 orang (16\%) yang berpendidikan sekolah dasar, sebanyak 8 orang (16\%) berpendidikan perguruan tinggi (diploma ataupun sarjana) dan 16 orang $(32 \%)$ yang berpendidikan sekolah menengah pertama.

Sebagian besar ayah di wilayah penelitian Kota Depok (representatif wilayah perkotaan) berpendidikan perguruan tinggi (baik diploma, sarjana taupun magister) yaitu sebanyak 76.0 persen. Ada sebanyak 2 orang (4\%) yang berpendidikan sekolah dasar, sebanyak 1 orang (2\%) berpendidikan sekolah menengah pertama dan sisanya berpendidikan sekolah menengah atas sebanyak 9 orang (18\%). Perbandingan pendidikan ayah responden di kedua wilayah juga dapat dilihat pada Gambar 1 di bawah ini:
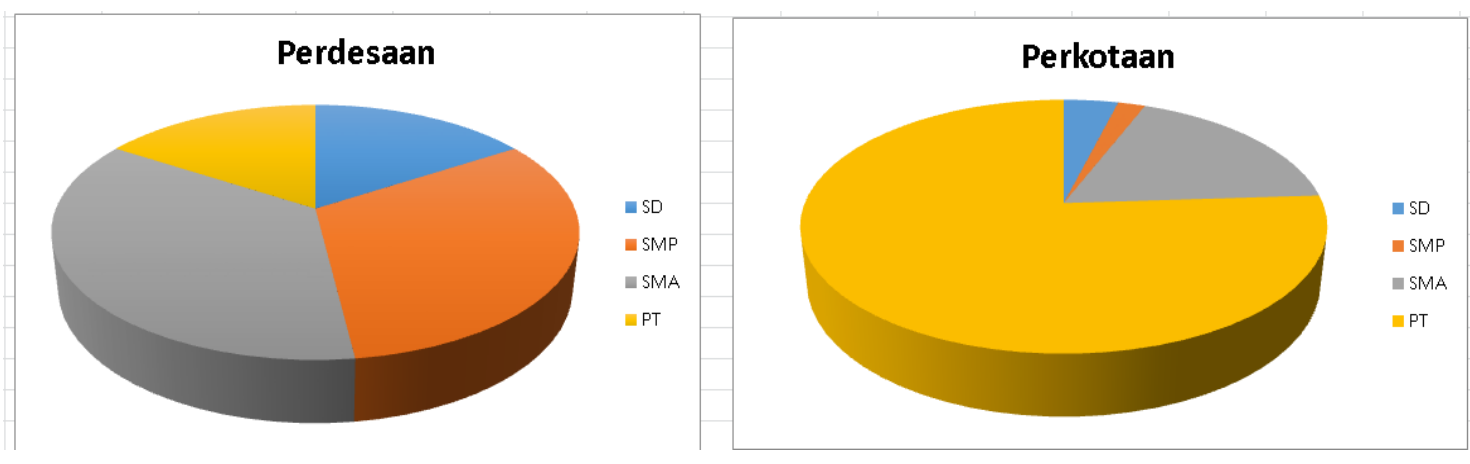

Gambar 1. Grafik persentase pendidikan ayah responden

Secara umum, tingkat pendidikan ibu responden di wilayah perkotaan lebih tinggi daripada di wilayah perdesaan. Ibu di wilayah perkotaan sebagian besar berpendidikan sampai jenjang perguruan tinggi yaitu sebanyak 54 persen, sedangkan di wilayah perdesaan, pendidikan Ibu sebagian besar berpendidikan sampai jenjang sekolah menengah atas yaitu sebanyak 34 persen. Perbandingan pendidikan ibu responden di kedua wilayah juga dapat dilihat pada Gambar 2 di bawah ini:
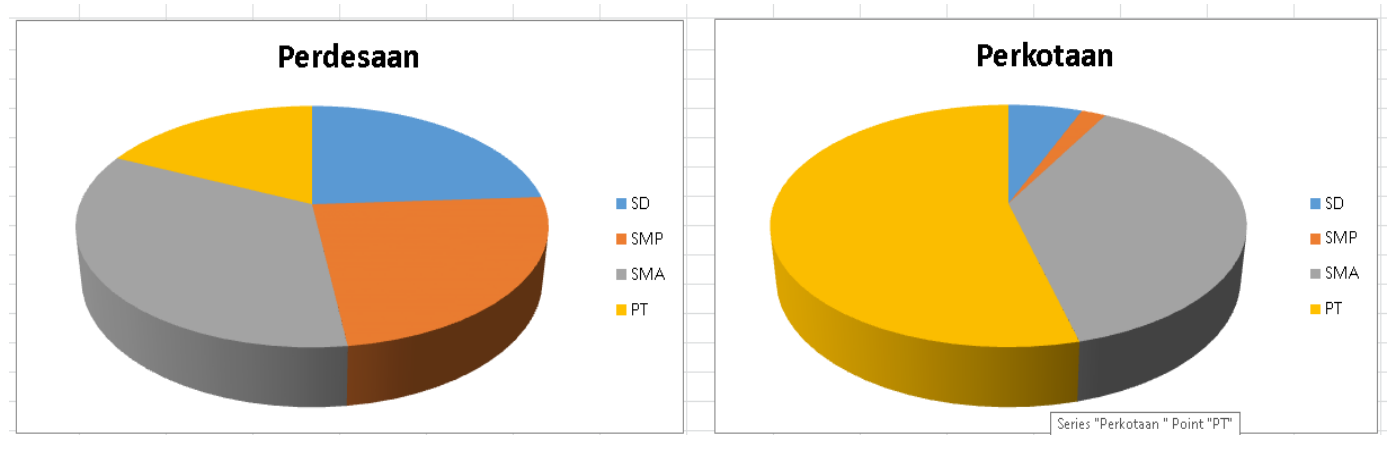

Gambar 2. Grafik Persentase pendidikan ibu responden

\section{Pekerjaan Orang Tua}

Hasil penelitian menunjukkan bahwa pekerjaan sebagian besar ayah di wilayah perdesaan adalah berwirausaha yaitu sebanyak 58 persen, sedangkan di wilayah perkotaan sebagai karyawan swasta yaitu sebanyak 46 persen. Di wilayah perdesaan, sebanyak 16 persen bekerja sebagai buruh dan 12 persen sebagai ASN, sedangkan di wilayah perkotaan 4 persen sebagai buruh dan 12 persen sebagai ASN atau karyawan BUMN. 
Persentase terbesar ibu di wilayah perkotaan berpendidikan sebagai sarjana, namun sebagian besar ibu dalam penelitian ini tidak bekerja di luar rumah atau melakukan profesinya sebagai ibu rumah tangga, yaitu sebanyak 78 persen. Begitu pula halnya dengan ibu di wilayah perdesaan yang mengabdikan dirinya sebagai ibu rumah tangga dan tidak bekerja di luar rumah ( 80 persen). Hal ini menunjukkan bahwa ibu-ibu yang berpendidikan tinggi tersebut lebih banyak menghabiskan waktunya di rumah, sehingga diharapkan dapat menciptakan lingkungan yang kondusif bagi perkembangan putra/putri mereka.

\section{Perilaku Nomophobia}

Tuntutan zaman pada akhirnya dapat memberikan ruang bagi banyak orang tua untuk mengenalkan gawai pada anak-anaknya bahkan sejak usia dini. Saat ini banyak ditemukan bahwa anak-anak yang berusia di bawah 6 tahun sudah mahir menggunakan gawai. Pada umumnya mereka menggunakan gawai untuk menonton video atau bermain games. Hal ini sesuai dengan hasil penelitian Indriyani (2016) bahwasanya anak-anak lebih suka menghabiskan waktunya untuk menonton film kartun dan bermain games atau mendengarkan musik dan menjelajah media sosial selama mereka sedang liburan sekolah (Fachrizal, 2018).

Menurut Fajri (2017) nomophobia atau biasa dikenal dengan "no mobile phone phobia" atau penyakit tidak bisa jauh-jauh dari gadget atau smartphone adalah suatu ketergantungan yang dialami seseorang sehingga dapat mendatangkan kekhawatiran yang berlebihan jika ponselnya tidak ada di dekatnya. Hasil penelitian ini menunjukkan bahwa skor rata-rata perilaku nomophobia di wilayah perdesaan adalah 35,61 , di wilayah perkotaan 35,72 yang yang termasuk dalam kategori rendah. Secara umum, skor rata-rata perilaku nomophobia adalah 35,61 yang termasuk dalam kategori rendah. Hal ini berarti bahwa anak usia dini di kedua wilayah tersebut masih dalam kondisi yang wajar dalam penggunaan gawai dan tidak dalam kondisi yang mengkhawatirkan. Namun kecenderungan penggunaan gawai sejak dini sudah mulai Nampak. Oleh karenanya hal ini tetap menjadi bahan perhatian bagi para orang tua khususnya orang tua dari anak usia dini. Hasil Uji beda (independent sample t-test) menunjukkan tidak ada perbedaan signifikan pada perilaku nomophobia baik di perdesaan maupun perkotaan.

Hasil uji t pada setiap butir perilaku nomophobia berdasarkan wilayah memperlihatkan adanya perbedaan pada skor rata-rata, namun perbedaan tersebut tidak signifikan. Perbandingan skor rata-rata perilaku nomophobia berdasarkan wilayah dapat dilihat pada Tabel 2.

Tabel 2. Skor rata-rata perilaku nomophobia berdasarkan wilayah

\begin{tabular}{|c|c|c|c|}
\hline \multirow{2}{*}{ Butir Pernyataan } & \multicolumn{2}{|c|}{ Skor rata-rata } & \multirow{2}{*}{$\begin{array}{l}\text { Hasil Uji } \\
\text { Beda }\end{array}$} \\
\hline & Perdesaan & Perkotaan & \\
\hline $\begin{array}{l}\text { 1. Jika tidak membawa HP saat bepergian, anak } \\
\text { saya akan merasa tidak nyaman }\end{array}$ & 1,92 & 1,98 & 0,658 \\
\hline $\begin{array}{l}\text { 2. Anak saya akan jengkel jika tidak bisa mencari } \\
\text { informasi di HP seperti yang diinginkan }\end{array}$ & 2,06 & 2,00 & 0,678 \\
\hline $\begin{array}{l}\text { 3. Anak saya gugup jika saat digunakan HP tiba-tiba } \\
\text { mati atau ada gangguan jaringan }\end{array}$ & 2,16 & 2,04 & 0,406 \\
\hline $\begin{array}{l}\text { 4. Anak saya akan terganggu jika tidak bisa } \\
\text { menggunakan HP sesuai keinginannya }\end{array}$ & 2,24 & 2,12 & 0,414 \\
\hline
\end{tabular}




\begin{tabular}{|c|c|c|c|c|}
\hline \multirow{2}{*}{\multicolumn{2}{|c|}{ Butir Pernyataan }} & \multicolumn{2}{|c|}{ Skor rata-rata } & \multirow{2}{*}{$\begin{array}{l}\text { Hasil Uji } \\
\text { Beda }\end{array}$} \\
\hline & & \multirow{2}{*}{$\begin{array}{l}\text { Perdesaan } \\
2,06\end{array}$} & \multirow{2}{*}{$\begin{array}{l}\text { Perkotaan } \\
1,84\end{array}$} & \\
\hline 5. & $\begin{array}{l}\text { Anak saya takut jika HP kehabisan baterai karena } \\
\text { tidak bisa main game kesukaannya }\end{array}$ & & & 0,125 \\
\hline 6. & $\begin{array}{l}\text { Anak saya panik jika paket data di HP sudah habis } \\
\text { karena tidak bisa main game online }\end{array}$ & 1,90 & 1,78 & 0,356 \\
\hline 7. & $\begin{array}{l}\text { Jika tidak ada sinyal atau tidak terhubung wifi , } \\
\text { maka anak saya terus berpindah tempat untuk } \\
\text { dapat terhubung dengan sinyal }\end{array}$ & 1,80 & 1,84 & 0,773 \\
\hline 8. & $\begin{array}{l}\text { Jika anak saya tidak bisa menggunakan HP, dia } \\
\text { seperti merasa asing berada di suatu tempat }\end{array}$ & 1,74 & 1,70 & 0,710 \\
\hline 9. & $\begin{array}{l}\text { Anak saya akan selalu mencari HP setiap ada } \\
\text { kesempatan }\end{array}$ & 2,18 & 2,40 & 0,117 \\
\hline 10. & $\begin{array}{l}\text { Anak saya akan merasa cemas jika tidak bisa } \\
\text { langsung berkomunikasi dengan teman atau yang } \\
\text { lainnya melalui HP }\end{array}$ & 1,68 & 1,72 & 0,731 \\
\hline 11. & $\begin{array}{l}\text { Anak saya akan khawatir karena temannya tidak } \\
\text { dapat menghubungi jika tidak memegang HP }\end{array}$ & 1,56 & 1,64 & 0,484 \\
\hline 12. & $\begin{array}{l}\text { Anak saya akan merasa gugup jika tidak dapat } \\
\text { menerima pesan atau bermain game online } \\
\text { dengan temannya }\end{array}$ & 1,54 & 1,72 & 0,133 \\
\hline 13. & $\begin{array}{l}\text { Jika tidak ada HP, anak saya akan cemas karena } \\
\text { tidak bisa berhubungan dengan temannya }\end{array}$ & 1,52 & 1,68 & 0,173 \\
\hline 14. & $\begin{array}{l}\text { Anak saya gugup jika merasa ragu apakah ada } \\
\text { yang menghubungi dia atau tidak }\end{array}$ & 1,52 & 1,56 & 0,713 \\
\hline 15. & $\begin{array}{l}\text { Jika tidak ada HP, anak saya akan merasa cemas } \\
\text { karena koneksi yang biasanya terus-menerus } \\
\text { dengan teman-temannya tiba-tiba akan terputus }\end{array}$ & 1,56 & 1,62 & 0,590 \\
\hline 16. & $\begin{array}{l}\text { Jika tidak ada HP, anak saya akan gugup karena } \\
\text { saya akan terputus dari identitas online nya }\end{array}$ & 1,60 & 1,62 & 0,872 \\
\hline 17. & $\begin{array}{l}\text { Anak saya akan merasa tidak nyaman jika tidak } \\
\text { bisa akses dengan media sosial atau jaringan } \\
\text { online }\end{array}$ & 1,62 & 1,68 & 0,642 \\
\hline 18. & $\begin{array}{l}\text { Anak saya akan merasa canggung jika tidak dapat } \\
\text { memeriksa notifikasi untuk pembaruan dari media } \\
\text { sosialnya }\end{array}$ & 1,56 & 1,54 & 0,859 \\
\hline 19. & $\begin{array}{l}\text { Anak saya akan merasa cemas karena tidak dapat } \\
\text { memeriksa pesan di HP }\end{array}$ & 1,60 & 1,58 & 0,870 \\
\hline 20. & $\begin{array}{l}\text { Jika tidak memegang HP, anak saya akan merasa } \\
\text { aneh karena tidak tahu harus berbuat apa }\end{array}$ & 1,68 & 1,66 & 0,882 \\
\hline
\end{tabular}

Hasil penelitian menunjukkan tidak ada perbedaan signifikan pada perilaku nomophobia antara wilayah perdesaan dan perkotaan. Hal ini disebabkan karena skor rata-rata untuk setiap indicator nomophobia relative sama yang menunjukkan bahwa secara umum anak-anak usia dini di kedua wilayah ini diindikasi sama perilakunya dalam hal penggunaan gawai. Skor rata-rata perilaku nomophobia berada dalam kategori rendah dimana anak usia dini di kedua 
wilayah ini masih dalam kondisi yang relative aman dalam penggunaan gawai. Namun demikian, beberapa indicator yang mengarah pada kecemasan atau ketidaknyamanan saat anak tidak memegang gawai harus menjadi perhatian orang tua agar tidak menimbulkan ketergantungan yang lebih jauh lagi dan membentuk perilaku nomophobia yang lebih parah. Seperti misalnya terlihat pada indicator pada "anak saya akan selalu mencari HP setiap ada kesempatan" yang menunjukkan skor rata-rata tertinggi diantara indicator perilaku nomophobia.

Berdasarkan kategori perilaku nomophobia dapat dilihat bahwa sebagian besar anakanak usia dini di kedua wilayah, baik perdesaan maupun perkotaan berada dalam kategori rendah, hanya sebagian yang berada dalam kategori sedang dan tidak satupun responden yang berada pada kategori perilaku nomophobia yang tinggi. Kategori perilaku nomophobia di kedua wilayah, dapat dilihat pada Tabel 3.

Tabel 3. Kategori Perilaku Nomophobia berdasarkan wilayah

\begin{tabular}{lll}
\hline \multirow{2}{*}{ Kategori } & \multicolumn{2}{l}{ Wilayah } \\
\cline { 2 - 3 } & Perdesaan & Perkotaan \\
\hline Rendah $(20-40)$ & $30(60 \%)$ & $31(62 \%)$ \\
Sedang $(41-60)$ & $20(40 \%)$ & $19(38 \%)$ \\
Tinggi $(61-80)$ & - & - \\
Jumlah & $50(100 \%)$ & $50(100 \%)$ \\
\hline
\end{tabular}

Jika dilihat berdasarkan jenis kelamin, sama halnya seperti pada wilayah, terdapat perbedaan pada skor rata-rata perilaku nomophobia namun tidak menunjukkan perbedaan yang signifikan. Skor rata-rata nomophobia pada anak perempuan $(36,65)$ lebih tinggi dibanding anak laki-laki $(34,72)$, seperti dapat terlihat pada Tabel 4. Indikator nomophobia yang menunjukkan skor tertinggi adalah pada saat anak usia dini akan mencari HP setiap ada kesempatan. Perilaku inilah yang hendaknya lebih menjadi focus perhatian orang tua agar anak tidak ketergantungan pada HP. Dalam hal ini hendaknya orang tua memberikan alternatif kegiatan lain yang dapat dilakukan bersama anak-anaknya, seperti membacakan buku cerita, melakukan kegiatan practical life skill seperti memasak, merapikan rumah, menyiram tanaman, memberi makan hewan peliharaan dan kegiatan-kegiatan bersama lainnya yang selain dapat mengalihkan perhatian anak dari HP juga dapat meningkatkan kompetensi dan menstimulasi tumbuh kembangnya.

Tabel 4. Skor rata-rata perilaku nomophobia berdasarkan jenis kelamin

\begin{tabular}{llll}
\hline \multirow{2}{*}{ Butir Pernyataan } & \multicolumn{2}{l}{ Skor rata-rata } & Hasil Uji \\
\cline { 2 - 3 } & Laki-laki & Perempuan & Beda \\
\hline 1. Jika tidak membawa HP saat bepergian, anak & 1,85 & 2,07 & 0,114 \\
$\begin{array}{l}\text { saya akan merasa tidak nyaman } \\
\text { 2. Anak saya akan jengkel jika tidak bisa mencari } \\
\text { informasi di HP seperti yang diinginkan }\end{array}$ & 1,98 & 2,09 & 0,466 \\
$\begin{array}{l}\text { Anak saya gugup jika saat digunakan HP tiba- } \\
\text { tiba mati atau ada gangguan jaringan }\end{array}$ & 2,02 & 2,20 & 0,220 \\
$\begin{array}{l}\text { Anak saya akan terganggu jika tidak bisa } \\
\text { menggunakan HP sesuai keinginannya }\end{array}$ & 2,15 & 2,22 & 0,639 \\
\hline
\end{tabular}




\begin{tabular}{|c|c|c|c|c|}
\hline \multirow{2}{*}{\multicolumn{2}{|c|}{ Butir Pernyataan }} & \multicolumn{2}{|c|}{ Skor rata-rata } & \multirow{3}{*}{$\begin{array}{l}\text { Hasil Uji } \\
\text { Beda } \\
0,358\end{array}$} \\
\hline & & \multirow{2}{*}{$\frac{\text { Laki-laki }}{1,89}$} & \multirow{2}{*}{$\begin{array}{l}\text { Perempuan } \\
2,02\end{array}$} & \\
\hline 5. & $\begin{array}{l}\text { Anak saya takut jika HP kehabisan baterai } \\
\text { karena tidak bisa main game kesukaannya }\end{array}$ & & & \\
\hline 6. & $\begin{array}{l}\text { Anak saya panik jika paket data di HP sudah } \\
\text { habis karena tidak bisa main game online }\end{array}$ & 1,89 & 1,78 & 0,416 \\
\hline 7. & $\begin{array}{l}\text { Jika tidak ada sinyal atau tidak terhubung wifi } \\
\text { maka anak saya terus berpindah tempat untuk } \\
\text { dapat terhubung dengan sinyal }\end{array}$ & 1,80 & 1,85 & 0,711 \\
\hline 8. & $\begin{array}{l}\text { Jika anak saya tidak bisa menggunakan HP, dia } \\
\text { seperti merasa asing berada di suatu tempat }\end{array}$ & 1,69 & 1,76 & 0,482 \\
\hline 9. & $\begin{array}{l}\text { Anak saya akan selalu mencari HP setiap ada } \\
\text { kesempatan }\end{array}$ & 2,22 & 2,37 & 0,297 \\
\hline 10. & $\begin{array}{l}\text { Anak saya akan merasa cemas jika tidak bisa } \\
\text { langsung berkomunikasi dengan teman atau } \\
\text { yang lainnya melalui HP }\end{array}$ & 1,67 & 1,74 & 0,534 \\
\hline 11. & $\begin{array}{l}\text { Anak saya akan khawatir karena temannya tidak } \\
\text { dapat menghubungi jika tidak memegang HP }\end{array}$ & 1,54 & 1,67 & 0,232 \\
\hline 12. & $\begin{array}{l}\text { Anak saya akan merasa gugup jika tidak dapat } \\
\text { menerima pesan atau bermain game online } \\
\text { dengan temannya }\end{array}$ & 1,57 & 1,70 & 0,313 \\
\hline 13. & $\begin{array}{l}\text { Jika tidak ada HP, anak saya akan cemas karena } \\
\text { tidak bisa berhubungan dengan temannya }\end{array}$ & 1,56 & 1,65 & 0,414 \\
\hline 14. & $\begin{array}{l}\text { Anak saya gugup jika merasa ragu apakah ada } \\
\text { yang menghubungi dia atau tidak }\end{array}$ & 1,50 & 1,59 & 0,425 \\
\hline 15. & $\begin{array}{l}\text { Jika tidak ada HP, anak saya akan merasa } \\
\text { cemas karena koneksi yang biasanya terus- } \\
\text { menerus dengan teman-temannya tiba-tiba akan } \\
\text { terputus }\end{array}$ & 1,54 & 1,65 & 0,301 \\
\hline 16. & $\begin{array}{l}\text { Jika tidak ada HP, anak saya akan gugup karena } \\
\text { saya akan terputus dari identitas online nya }\end{array}$ & 1,56 & 1,67 & 0,342 \\
\hline 17. & $\begin{array}{l}\text { Anak saya akan merasa tidak nyaman jika tidak } \\
\text { bisa akses dengan media sosial atau jaringan } \\
\text { online }\end{array}$ & 1,63 & 1,67 & 0,733 \\
\hline 18. & $\begin{array}{l}\text { Anak saya akan merasa canggung jika tidak } \\
\text { dapat memeriksa notifikasi untuk pembaruan dari } \\
\text { media sosialnya }\end{array}$ & 1,52 & 1,59 & 0,543 \\
\hline 19. & $\begin{array}{l}\text { Anak saya akan merasa cemas karena tidak } \\
\text { dapat memeriksa pesan di HP }\end{array}$ & 1,56 & 1,63 & 0,540 \\
\hline 20. & $\begin{array}{l}\text { Jika tidak memegang HP, anak saya akan } \\
\text { merasa aneh karena tidak tahu harus berbuat } \\
\text { apa }\end{array}$ & 1,61 & 1,74 & 0,342 \\
\hline Tota & & 34,72 & 36,65 & 0,295 \\
\hline
\end{tabular}


Nomophobia atau biasa dikenal dengan singkatan "No Mobile Phone Phobia" atau penyakit tidak bisa jauh-jauh dari smartphone merupakan suatu penyakit ketergantungan yang dialami seorang individu terhadap smartphone, sehingga bisa mendatangkan kekhawatiran yang berlebihan jika ponselnya tidak ada di dekatnya (Fajri, 2017). Dasiroh (2018) memperkenalkan istilah nomophobe dan nomophobic bagi orang-orang dengan nomophobia. Kondisi penggunaan smartphone yang berlebihan dan kompulsivitas penggunaan smartphone seperti yang telah diungkapkan oleh Caglar (dalam Prasetyo, 2016) mengarah pada gangguan kecemasan baru yang disebut dengan nomophobia. King (dalam Prasetyo dkk., 2016) menyatakan bahwa nomophobia dianggap sebagai gangguan yang modern dan baru-baru ini telah digunakan untuk menggambarkan ketidaknyamanan atau kecemasan yang disebabkan oleh tidak berada dekat dengan perangkat komunikasi virtual seperti telepon genggam. Ketakutan akan rasa kesepian membuat individu menggunakan smartphone sebagai alat komunikasi dan mendapatkan informasi yang terlalu berlebihan sehingga mengalami nomophobia (Prasetyo dkk., 2016).

Penggunaan gawai atau gadget merupakan suatu hal yang wajar di masa kini karena keberadaan benda ini sudah seperti menjadi sesuatu yang wajib dibawa kemanapun individu berada. Fungsinya yang beranekaragam seperti sebagai alat komunikasi, perangkat bermain game, berjejaring sosial, membuat dan mengedit foto dan video, atau bahkan untuk melakukan pekerjaan-pekerjaan yang biasanya dilakukan oleh perangkat lain seperti misalnya alarm, mesin penghitung dan mesin pencari informasi yang canggih, menjadikan gawai sebagai barang berharga yang tidak boleh lepas dari tangan kapanpun dimanapun. Berbagai fitur dan fasilitas yang menarik ini semakin membelenggu para penggunanya agar terus bersama dengan gawainya dalam setiap kesempatan sehingga menjadi kecanduan. Dengan beragamnya fitur serta kecanggihan yang ditawarkan ponsel pintar membuat pengguna semakin merasa dimanjakan serta tergantung dalam kehidupan sehari-hari dalam penggunaannya. Kecanggihan gadget yang menawarkan segala macam kemudahan dan kemampuan untuk dalam memenuhi kebutuhan individu masa kini membuat para pengguna semakin merasa tergantung dan bahkan akan merasa cemas jika tidak bersentuhan dengan gawainya. Kondisi seperti inilah yang disebut dengan nomophobia. Nomophobia selain dapat menyebabkan ketergantungan juga dapat menimbulkan stres pada penderitanya. Penelitian di Inggris menemukan bahwa sekitar 9 persen dari jumlah partisipan merasakan stres ketika gawai mereka mati atau tidak berfungsi (Endah, 2016). Begitu pula penelitian yang dilakukan oleh Jones menemukan bahwa 25,8 persen dari jumlah partisipan merasakan stres ketika mereka tidak membawa gawai atau ponsel pintarnya (Endah, 2016).

Penelitian yang dilakukan oleh Mayangsari (2014) menemukan bahwa di Indonesia, jumlah pengidap nomophobia mengalami peningkatan yang signifikan, pada tahun 2013 sekitar 75 persen dengan rentang usia 18-24 tahun dan tahun 2014 pengidap nomophobia sekitar 84 persen direntang usia 19-24 tahun. Lebih jauh, Penelitian Mayangsari (2014) menerangkan bahwa nomophobia pada wanita lebih besar jumlahnya dibanding laki-laki, yaitu sekitar 56 persen dibandingkan laki-laki 47 persen pada rentang usia 18-24 tahun. Walaupun masih jarang, namun pada kelompok anak usia dini, beberapa penelitian juga sudah dilakukan terkait dengan penggunaan gawai ini. Diantaranya penelitian yang dilakukan oleh Indriyani dkk (2018) menemukan bahwa anak sudah mengenal gawai sejak usia 2 tahun. Sebagian besar anak usia dini menggunakan gawainya untuk menonton film kartun, bermain games atau menonton youtube.

\section{Perilaku Sosial}

Perilaku sosial merupakan pencapaian seseorang kematangan seseorang dalam hubungan sosial sebagai proses belajar untuk menyesuaikan diri terhadap norma-norma kelompok, moral, tradisi, serta membaur menjadi satu kesatuan dan saling bekerja sama. Perilaku sosial terdiri atas dimensi perilaku prososial dan antisosial. Hasil penelitian 
menunjukkan bahwa skor rata-rata perilaku sosial yaitu 118,60 (perdesaan) dan 118,68 (perkotaan) berada dalam kategori tinggi. Melalui uji T Test tidak terdapat perbedaan signifikan pada perilaku sosial di wilayah perdeasaan dan perkotaan. Hal ini berarti secara umum anak usia dini baik di perdesaan maupun perkotaan memiliki perilaku sosial yang relative sama dan memiliki perilaku sosial yang baik. Sebaran responden di kedua wilayah dalam perilaku sosial berada dalam kategori tinggi (64 persen) dan sedang (36 persen) dalam perilaku sosial, serta tidak satupun responden menunjukkan indikasi perilaku sosial dengan kategori rendah.

Walaupun secara umum, hasil penelitian tidak menunjukkan perbedaan signifikan pada perilaku sosial di wilayah perdesaan maupun perkotaan, namun terlihat ada beberapa indicator yang menunjukkan perbedaan signifikan, yaitu antara lain pada dimensi persaingan dimana anak di wilayah perkotaan lebih senang mengikuti berbagai lomba (signifikan pada taraf nyata 95\%). Anak usia dini di perdesaan lebih mudah marah jika keinginannya tidak dituruti dan lebih suka bertengkar dengan temannya (signifikan pada taraf nyata 95\%). Penemuan in hampir serupa dengan penelitian yang dilakukan Magdalena dkk (2016) bahwa sikap agresivitas (yang termasuk dalam perilaku sosial) remaja di perdesaan lebih tinggi dibanding di perkotaan, artinya remaja perdesaan lebih menunjukkan sikap-sikap agresif dibanding dengan remaja di perkotaan yang kemungkinan disebabkan karena factor geografis yang kurang mendukung pola pengasuhan yang kurang tepat sehingga menimbulkan munculnya perilaku agresif.

Tabel 5. Perbandingan Skor rata-rata Perilaku Sosial Berdasarkan Wilayah

\begin{tabular}{|c|c|c|c|c|}
\hline \multirow{2}{*}{\multicolumn{2}{|c|}{ Butir Pertanyaan }} & \multicolumn{2}{|c|}{ Skor rata-rata } & \multirow{3}{*}{$\begin{array}{l}\text { Hasil Uj } \\
\text { Beda } \\
0,401\end{array}$} \\
\hline & & \multirow{2}{*}{$\begin{array}{l}\text { Perdesaan } \\
3,50\end{array}$} & \multirow{2}{*}{$\begin{array}{l}\text { Perkotaan } \\
3,60\end{array}$} & \\
\hline 1. & $\begin{array}{l}\text { Anak saya mau bermain bersama teman- } \\
\text { temannya }\end{array}$ & & & \\
\hline 2. & $\begin{array}{l}\text { Anak saya senang berkumpul dengan teman- } \\
\text { temannya }\end{array}$ & 3,48 & 3,54 & 0,635 \\
\hline 3. & Anak saya senang ikut berbagai lomba & 2,22 & 2,62 & 0,020 \\
\hline 4. & $\begin{array}{l}\text { Bagi anak saya, tidak masalah menang atau } \\
\text { kalah, saat ikut lomba }\end{array}$ & 2,52 & 2,66 & 0,514 \\
\hline 5. & $\begin{array}{l}\text { Anak saya senang berbagi makanan dengan } \\
\text { orang lain atau dengan temannya }\end{array}$ & 3,24 & 3,00 & 0,132 \\
\hline 6. & $\begin{array}{l}\text { Anak saya mau meminjamkan mainan atau } \\
\text { barang milikinya kepada temannya }\end{array}$ & 3,00 & 3,12 & 0,450 \\
\hline 7. & $\begin{array}{l}\text { Anak saya selalu berusaha untuk bersikap baik } \\
\text { pada temannya agar diajak main }\end{array}$ & 3,10 & 3,24 & 0,380 \\
\hline 8. & Anak saya mudah bersosialisasi & 3,30 & 3,20 & 0,519 \\
\hline 9. & $\begin{array}{l}\text { Anak saya senang menghibur temannya yang } \\
\text { sedih atau menangis }\end{array}$ & 2,68 & 2,42 & 0,130 \\
\hline 10. & $\begin{array}{l}\text { Anak saya bertanya jika ada teman yang } \\
\text { bersedih }\end{array}$ & 2,50 & 2,52 & 0,907 \\
\hline 11. & $\begin{array}{l}\text { Anak saya akan mendekati teman yang terjatuh } \\
\text { atau terluka }\end{array}$ & 2,84 & 2,60 & 0,137 \\
\hline 12. & $\begin{array}{l}\text { Anak saya ikut merasa sedih jika melihat ada } \\
\text { yang bersedih }\end{array}$ & 2,62 & 2,46 & 0,360 \\
\hline
\end{tabular}




\begin{tabular}{|c|c|c|c|c|}
\hline \multirow{2}{*}{\multicolumn{2}{|c|}{ Butir Pertanyaan }} & \multicolumn{2}{|c|}{ Skor rata-rata } & \multirow{2}{*}{$\begin{array}{l}\text { Hasil Uj } \\
\text { Beda }\end{array}$} \\
\hline & & \multirow{2}{*}{$\begin{array}{l}\text { Perdesaan } \\
2,72\end{array}$} & \multirow{2}{*}{$\begin{array}{l}\text { Perkotaan } \\
2,72\end{array}$} & \\
\hline 13. & $\begin{array}{l}\text { Anak saya minta tolong pada orang lain jika } \\
\text { mengalami kesulitan }\end{array}$ & & & 1,000 \\
\hline 14. & Anak saya mencari teman untuk diajak bermain & 3,36 & 3,22 & 0,339 \\
\hline 15. & $\begin{array}{l}\text { Anak saya bertegur sapa jika bertemu dengan } \\
\text { orang yang dikenalnya }\end{array}$ & 3,00 & 3,04 & 0,808 \\
\hline 16. & $\begin{array}{l}\text { Anak saya menjawab pertanyaan jika ada yag } \\
\text { bertanya }\end{array}$ & 3,16 & 2,98 & 0,252 \\
\hline 17. & $\begin{array}{l}\text { Anak saya mau membantu temannya yang } \\
\text { sedang dalam kesulitan }\end{array}$ & 2,70 & 2,70 & 1,000 \\
\hline 18. & $\begin{array}{l}\text { Jika bermain bersama, anak saya mau } \\
\text { mengalah demi kepentingan bersama }\end{array}$ & 2,58 & 2,60 & 0,897 \\
\hline 19. & $\begin{array}{l}\text { Anak saya bisa mengikuti aturan dalam } \\
\text { permainan }\end{array}$ & 2,96 & 2,76 & 0,256 \\
\hline 20. & Anak saya suka meniru gaya bicara gurunya & 2,28 & 2,14 & 0,503 \\
\hline 21. & $\begin{array}{l}\text { Anak saya dapat menjalin hubungan } \\
\text { persahabatan }\end{array}$ & 3,14 & 3,08 & 0,723 \\
\hline 22. & Anak saya termasuk orang yang setia kawan & 3,24 & 3,08 & 0,362 \\
\hline 23. & Jika dinasehati, anak saya suka melawan & 3,16 & 3,16 & 1,000 \\
\hline 24. & $\begin{array}{l}\text { Jika keinginannya tidak dituruti, anak saya akan } \\
\text { marah }\end{array}$ & 2,58 & 2,90 & 0,025 \\
\hline 25. & Anak saya suka merebut barang orang lain & 3,66 & 3,62 & 0,731 \\
\hline 26. & Anak saya suka memaksakan kehendaknya & 3,12 & 3,10 & 0,881 \\
\hline 27. & Anak saya suka bertengkar dengan temannya & 3,00 & 3,24 & 0,025 \\
\hline 28. & Anak saya suka adu mulut dengan temannya & 3,26 & 3,40 & 0,248 \\
\hline 29. & Anak saya suka mengejek temannya & 3,62 & 3,66 & 0,693 \\
\hline & Anak saya suka membentak orang lain & 3,66 & 3,70 & 0,672 \\
\hline & Sikap anak saya seperti bos kecil & 3,48 & 3,38 & 0,503 \\
\hline 32. & Anak saya suka menguasai teman & 3,72 & 3,68 & 0,723 \\
\hline & Anak saya ingin menang sendiri & 3,52 & 3,46 & 0,606 \\
\hline & Anak saya tidak mau mengalah & 3,18 & 3,36 & 0,167 \\
\hline 35. & $\begin{array}{l}\text { Anak saya memilih teman-teman yang } \\
\text { disukainya saja }\end{array}$ & 3,40 & 3,40 & 1,000 \\
\hline 36. & Anak saya mudah curiga & 3,86 & 3,64 & 0,016 \\
\hline 37. & $\begin{array}{l}\text { Anak saya selalu menghindar untuk bermain } \\
\text { dengan lawan jenis }\end{array}$ & 3,24 & 3,74 & 0,001 \\
\hline \multirow[t]{2}{*}{38.} & $\begin{array}{l}\text { Anak saya suka merendahkan teman yang } \\
\text { berbeda lawan jenis }\end{array}$ & 4,00 & 3,94 & 0,080 \\
\hline & TOTAL & 118,60 & 118,68 & 0,840 \\
\hline
\end{tabular}


Sears (1994) berpendapat bahwa perilaku prososial adalah tindakan menolong yang sepenuhnya dimotivasi oleh kepentingan sendiri tanpa mengharapkan sesuatu untuk diri si penolong itu sendiri. Perilaku prososial merupakan bagian dari kehidupan sehari- hari. Perilaku prososial muncul atas inisiatifnya sendiri bukan karena paksaan atau tekanan dari luar. Tidak semua individu juga akan memberikan pertolongan ataupun berperilaku prososial pada individu lain yang membutuhkan, karena tiap individu memiliki alasan tertentu untuk melakukan atau tidak melakukan sesuatu. Perbandingan skor rata-rata perilaku sosial berdasarkan jenis kelamin dalam penelitian ini menunjukkan adanya perbedaan signifikan secara total pada taraf nyata $90 \%$ (taraf signifikansi 0,093 ), dimana skor rata-rata anak perempuan $(120,63)$ lebih tinggi dibanding anak laki-laki $(116,94)$.

Pada beberapa indikator juga terlihat perbedaan yang signifikan antara anak laki-laki dan perempuan, seperti pada indikator meniru gaya bicara guru, suka melawan jika dinasehati, marah jika keinginan tidak dituruti dan suka bertengkar dengan temannya, dimana anak lakilaki memiliki skor rata-rata lebih rendah daripada anak perempuan dan berbeda secara siginfikan pada taraf nyata 90 sampai dengan 95 persen. Namun pada indicator senang berkumpul dengan teman-temannya, anak laki-laki memiliki skor yang lebih tinggi $(3,63)$ dibanding anak perempuan $(3,37)$ yang berbeda signifikan pada taraf nyata 95 persen. Hal ini sejalan dengan penelitian yang dilakukan oleh Istiana (2018) yang menemukan bahwa lakikali memiliki skor rata-rata prilaku prososial yang lebih tinggi dibanding perempuan. Perilaku sosial ini tentu banyak dipengaruhi oleh pola pengasuhan dalam keluarga dan dukungan lingkungan terdekat seperti hasil penelitian Fauzi (2013) yang menemukan bahwa terdapat hubungan antara keharmonisan keluarga dan dukungan sosial teman sebaya dengan perilaku prososial remaja.

Tabel 6. Perbandingan Skor rata-rata Perilaku Sosial Berdasarkan Jenis Kelamin

\begin{tabular}{|c|c|c|c|c|}
\hline \multirow{2}{*}{\multicolumn{2}{|c|}{ Butir Pertanyaan }} & \multicolumn{2}{|c|}{ Skor rata-rata } & \multirow{2}{*}{$\begin{array}{l}\text { Hasil Uji } \\
\text { Beda }\end{array}$} \\
\hline & & \multirow{2}{*}{$\frac{\text { Laki-laki }}{3,56}$} & \multirow{2}{*}{$\begin{array}{l}\text { Perempuan } \\
3,54\end{array}$} & \\
\hline 1. & $\begin{array}{l}\text { Anak saya mau bermain bersama teman- } \\
\text { temannya }\end{array}$ & & & 0,920 \\
\hline 2. & $\begin{array}{l}\text { Anak saya senang berkumpul dengan teman- } \\
\text { temannya }\end{array}$ & 3,63 & 3,37 & 0,038 \\
\hline 3. & Anak saya senang ikut berbagai lomba & 2,37 & 2,48 & 0,538 \\
\hline 4. & $\begin{array}{l}\text { Bagi anak saya, tidak masalah menang atau } \\
\text { kalah, saat ikut lomba }\end{array}$ & 2,65 & 2,52 & 0,557 \\
\hline 5. & $\begin{array}{l}\text { Anak saya senang berbagi makanan dengan } \\
\text { orang lain atau dengan temannya }\end{array}$ & 3,04 & 3,22 & 0,260 \\
\hline 6. & $\begin{array}{l}\text { Anak saya mau meminjamkan mainan atau } \\
\text { barang milikinya kepada temannya }\end{array}$ & 3,11 & 3,00 & 0,486 \\
\hline 7. & $\begin{array}{l}\text { Anak saya selalu berusaha untuk bersikap baik } \\
\text { pada temannya agar diajak main }\end{array}$ & 3,17 & 3,17 & 0,964 \\
\hline 8. & Anak saya mudah bersosialisasi & 3,31 & 3,17 & 0,365 \\
\hline & $\begin{array}{l}\text { Anak saya senang menghibur temannya yang } \\
\text { sedih atau menangis }\end{array}$ & 2,43 & 2,70 & 0,117 \\
\hline & $\begin{array}{l}\text { Anak saya bertanya jika ada teman yang } \\
\text { bersedih }\end{array}$ & 2,39 & 2,65 & 0,122 \\
\hline & $\begin{array}{l}\text { Anak saya akan mendekati teman yang } \\
\text { terjatuh atau terluka }\end{array}$ & 2,70 & 2,74 & 0,828 \\
\hline
\end{tabular}




\begin{tabular}{|c|c|c|c|c|}
\hline 12. & $\begin{array}{l}\text { Anak saya ikut merasa sedih jika melihat ada } \\
\text { yang bersedih }\end{array}$ & 2,44 & 2,65 & 0,236 \\
\hline 13. & $\begin{array}{l}\text { Anak saya minta tolong pada orang lain jika } \\
\text { mengalami kesulitan }\end{array}$ & 2,72 & 2,72 & 0,978 \\
\hline 14. & $\begin{array}{l}\text { Anak saya mencari teman untuk diajak } \\
\text { bermain }\end{array}$ & 3,31 & 3,26 & 0,714 \\
\hline 15. & $\begin{array}{l}\text { Anak saya bertegur sapa jika bertemu dengan } \\
\text { orang yang dikenalnya }\end{array}$ & 3,11 & 2,91 & 0,228 \\
\hline 16. & $\begin{array}{l}\text { Anak saya menjawab pertanyaan jika ada yag } \\
\text { bertanya }\end{array}$ & 3,09 & 3,04 & 0,756 \\
\hline 17. & $\begin{array}{l}\text { Anak saya mau membantu temannya yang } \\
\text { sedang dalam kesulitan }\end{array}$ & 2,61 & 2,80 & 0,222 \\
\hline 18. & $\begin{array}{l}\text { Jika bermain bersama, anak saya mau } \\
\text { mengalah demi kepentingan bersama }\end{array}$ & 2,52 & 2,67 & 0,315 \\
\hline 19. & $\begin{array}{l}\text { Anak saya bisa mengikuti aturan dalam } \\
\text { permainan }\end{array}$ & 2,78 & 2,96 & 0,312 \\
\hline 20. & Anak saya suka meniru gaya bicara gurunya & 2,00 & 2,46 & 0,028 \\
\hline 21. & $\begin{array}{l}\text { Anak saya dapat menjalin hubungan } \\
\text { persahabatan }\end{array}$ & 3,06 & 3,17 & 0,485 \\
\hline 22. & Anak saya termasuk orang yang setia kawan & 3,15 & 3,17 & 0,884 \\
\hline 23. & Jika dinasehati, anak saya suka melawan & 3,04 & 3,30 & 0,021 \\
\hline 24. & $\begin{array}{l}\text { Jika keinginannya tidak dituruti, anak saya } \\
\text { akan marah }\end{array}$ & 2,57 & 2,93 & 0,012 \\
\hline 25. & Anak saya suka merebut barang orang lain & 3,61 & 3,67 & 0,591 \\
\hline 26. & Anak saya suka memaksakan kehendaknya & 3,11 & 3,11 & 0,986 \\
\hline 27. & Anak saya suka bertengkar dengan temannya & 3,02 & 3,24 & 0,040 \\
\hline 28. & Anak saya suka adu mulut dengan temannya & 3,15 & 3,54 & 0,001 \\
\hline 29. & Anak saya suka mengejek temannya & 3,57 & 3,72 & 0,157 \\
\hline 30. & Anak saya suka membentak orang lain & 3,61 & 3,76 & 0,112 \\
\hline 31. & Sikap anak saya seperti bos kecil & 3,31 & 3,57 & 0,093 \\
\hline 32. & Anak saya suka menguasai teman & 3,63 & 3,78 & 0,174 \\
\hline 33. & Anak saya ingin menang sendiri & 3,46 & 3,52 & 0,614 \\
\hline 34. & Anak saya tidak mau mengalah & 3,19 & 3,37 & 0,158 \\
\hline 35. & $\begin{array}{l}\text { Anak saya memilih teman-teman yang } \\
\text { disukainya saja }\end{array}$ & 3,30 & 3,52 & 0,114 \\
\hline 36. & Anak saya mudah curiga & 3,74 & 3,76 & 0,828 \\
\hline 37. & $\begin{array}{l}\text { Anak saya selalu menghindar untuk bermain } \\
\text { dengan lawan jenis }\end{array}$ & 3,52 & 3,46 & 0,696 \\
\hline \multirow[t]{2}{*}{38.} & $\begin{array}{l}\text { Anak saya suka merendahkan teman yang } \\
\text { berbeda lawan jenis }\end{array}$ & 3,96 & 3,98 & 0,659 \\
\hline & Total & 116,94 & 120,63 & 0,093 \\
\hline
\end{tabular}




\section{E. Hubungan perilaku nomophobia dan perilaku sosial}

Hubungan antar dua variable penelitian menggunakan analisi korelasi sederhana (bivariate correlation). Dengan analisis ini dapat diketahui keeratan hubungan dan juga arah hubungan yang terjadi. Koefisien korelasi sederhana menunjukkan seberapa besar hubungan yang terjadi antara dua variable penelitian. Hasil penelitian ini menunjukkan bahwa koefisien korelasi antar dua variable penelitian yaitu perilaku nomophobia dan perilaku sosial adalah 0,085 dan menunjukkan arah negative. Arah negative menunjukkan hubungan terbalik yang artinya semakin tinggi variable $\mathrm{X}$ maka akan semakin rendah variable $\mathrm{Y}$.

Tabel 7. Hasil uji korelasi antar dua variable penelitian

\begin{tabular}{llll}
\hline & & Perilaku Nomophobia & Perilaku Sosial \\
\hline Perilaku & Pearson Correlation & 1 & -.085 \\
Nomophobia & Sig. (2-tailed) & & .400 \\
& $\mathrm{~N}$ & 100 & 100 \\
Perilaku & Pearson Correlation & -.085 & 1 \\
Sosial & Sig. (2-tailed) & .400 & \\
& $\mathrm{~N}$ & 100 & 100 \\
\hline
\end{tabular}

Hasil penelitian ini menunjukkan koefisien korelasi adalah 0,085 dengan signifikansi 0,400. Karena taraf signifikansi 0,400>0,05 maka dapat disimpulkan tidak ada hubungan yang signifikan antara perilaku nomophobia dan perilaku sosial anak usia dini, serta dari tabel interpretasi koefisien korelasi menurut Sugiyono, korelasinya termasuk kategori sangat lemah. $\mathrm{Hal}$ ini kemungkinan disebabkan karena masih terdapat factor lain yang lebih mempengaruhi perilaku sosial. Namun adanya nilai korelasi Pearson yang bernilai negative, yaitu $-0,085$ menunjukkan arah hubungan yang negative yang artinya semakin tinggi perilaku nomophobia maka akan semakin rendah perilaku sosial yang ditunjukkan oleh anak usia dini atau sebaliknya. Hal ini menunjukkan adanya kecenderungan terindikasinya perilaku nomophobia pada anak usia dini yang akan menimbulkan penurunan terhadap perilaku sosial. Bagaimanapun, hal ini tentu menjadi peringatan dini bagi kita semua selaku orang tua dan para pendidik anak usia dini untuk lebih mengawasi pemakaian gawai atau gadget agar tidak menimbulkan gejala nomophobia yang tentu akan merusak perilaku serta masa depan anakanak.

Hal ini sejalan dengan penelitian yang dilakukan Mulyana dkk (2017). Hubungan negatif antara variable harga diri dengan smartpone addiction pada remaja SMA di kota Banda Aceh. Penelitian ini menunjukkan semakin tinggi harga diri yang dimiliki maka semakin rendah resiko remaja untuk mengalami smartphone addiction dan sebaliknya. Begitu pula dengan penelitian Wibowo (2020) menemukan bahwa tidak ada hubungan antara dukungan sosial dan nomophobia pada remaja, namun nilai koefisien korelasi pearson bersifat negative yang artinya semakin tinggi tingkat dukungan sosial maka semakin rendah tingkat nomophobia pada remaja ataupun sebaliknya.

Penelitian nomophobia di kalangan anak usia dini tentu menjadi hal yang juga prioritas mengingat anak usia dini pada masa sekarang ini sudah banyak terpapar gawai atau gadget, apalagi anak usia dini berada masa meniru atau imitasi. Penelitian tentang nomophobia selama ini lebih banyak dilakukan di kalangan remaja. Penelitian yang dilakukan oleh Wibowo (2020) menunjukkan bahwa tidak ada hubungan yang signifikan antara dukungan sosial dan nomophobia pada remaja, namun sama halnya dengan penelitian ini, korelasi Pearson menunjukkan nilai negative yang artinya semakin rendah dukungan sosial maka akan semakin tinggi perilaku nomophobia. 
Menurut Mayangsari (2015), hubungan individu dengan smartphone sangat mempengaruhi perilaku interpersonal dan kebiasaan sosial. Teknologi komunikasi juga membuat perubahan dalam interaksi masyarakat dengan dunia, persepsi pada interaksi yang nyata dan interaksi lewat smartphone. Ikatan yang berkualitas dengan orang lain secara universal merupakan bagian dari kehidupan yang optimal. Sebagian besar interaksi antara orang tua dengan anak memiliki implikasi di masa depan karena keluarga adalah tempat belajar bagaimana berhubungan dengan orang lain. Secara umum, memiliki teman adalah hal yang baik karena dapat mendorong self esteem dan menolong dalam mengatasi stres (Baron dkk., 2005). Penelitian di Indonesia tentang nomophobia pada anak usia dini masih minuim bahkan mungkin belum ditemukan. Namun penelitian di kalangan remaja telah dilakukan oleh Mayangsari dkk. (2015) yaitu tentang hubungan antara self esteem dengan kecenderungan nomophobia pada remaja. Hasil penelitian tersebut menunjukkan tidak terdapat relasi yang signifikan antara self-esteem dengan kecenderungan nomophobia pada remaja. Hal tersebut berbeda dengan penelitian di luar negeri yang telah dilakukan oleh Ehrenberg dkk. (2008) yang menyatakan bahwa self-esteem merupakan prediktor yang kuat bagi individu untuk mengalami kecanduan telepon genggam.

Ada pula penelitian lainnya tentang nomophobia telah dilakukan oleh Asih dkk. (2017) tentang hubungan antara kontrol diri dengan kecemasan jauh dari smartphone (nomophobia) pada mahasiswa yang menunjukkan bahwa kontrol diri hanya memberikan sumbangsih efektif yang kecil terhadap nomophobia yaitu sebesar 4,3\%. Sisanya sebesar $95,7 \%$ ditentukan oleh faktor-faktor lain. Sedangkan penelitian yang dilakukan oleh Sudarji (2017) tentang hubungan antara nomophobia dengan kepercayaan diri memperkuat dari penelitian-penelitian sebelumnya. Dari hasil yang diperoleh menunjukkan bahwa tidak terdapat hubungan antara nomophobia dengan kepercayaan diri.

Selain itu, ada pula penelitian yang menunjukkan hubungan positif siginifikan antara penggunaan smartphone dengan nomophobia pada mahasiswa (Fajri, 2017). Penelitian mengenai hubungan impulsif dengan kecenderungan nomophobia yang pernah dilakukan oleh Mawardi (2018) tentang hubungan antara perilaku impulsif dengan kecenderungan nomophobia pada remaja menunjukkan hubungan yang signifikan $(0,006<0.05)$. Penelitian yang dilakukan oleh Aldianita dkk. (2017) tentang hubungan kontrol diri dan perilaku impulsif dengan nomophobia pada remaja pengguna instagram di kelas XI IPS SMAN 31 Jakarta Timur menunjukkan bahwa ada hubungan yang signifikan arah positif antara perilaku impulsif dengan nomophobia dengan nilai $r=0,280$ dan $p=0,002<0,05$. Hal ini berarti bahwa semakin tinggi tingkat perilaku impulsif siswa maka semakin tinggi pula tingkat kecenderungan nomophobia. Selain dari faktor perilaku impulsif, penelitian sebelumnya yang dilakukan oleh Wijayanti pada tahun 2017 pernah meneliti tentang perilaku pengguna jejaring sosial dengan judul hubungan perilaku penggunaan jejaring sosial dengan nomophobia. Hasil menunjukkan adanya hubungan positif yang signifikan antara perilaku penggunaan jejaring sosial dengan nomophobia dengan sumbangan efektif sebesar $34,9 \%$ dengan nilai $p<0,05$. Hal ini menunjukkan bahwa semakin tinggi perilaku penggunaan jejaring sosial maka semakin tinggi nomophobia yang dialami mahasiswa.

Penelitian di laboratorium Universitas Rio de Janeiro, Brasil, jika dibandingkan, orang dengan gangguan panic dan orang yang sehat, maka pada orang dengan gangguan panic akan menunjukkan peningkatan signifikan dalam kecemasan, perubahan pernapasan, gemetar, berkeringat, ketakutan dan depresi terkait dengan kurangnya penggunaan gawai. Penelitian ini menunjukkan baik pada orang dengan gangguan panic ataupun orang yang sehat, keduanya menunjukkan ketergantungan dan akan merasa terhibur dengan adanya gawai, namun orang dengan gangguan panic menunjukkan perubahan yang jauh lebih emosional serta gejala fisik dan psikologis yang intens ketika mereka terpisah dari gawai atau tidak dapat menggunakan gawai (King, et al., 2014). Hal ini juga diperkuat pada penelitian di Turki yang dilakukan oleh Yildirim (2015). Penelitian yang melibatkan 537 mahasiswa ini mengungkapkan bahwa sebanyak 42,6 persen orang dewasa muda memiliki kecenderungan 
nomophobia dan ketakutan terbesar mereka terkait dengan akses komunikasi dan informasi. Studi ini juga menemukan bahwa jenis kelamin dan durasi kepemilikan smartphone berpengaruh pada perilaku nomophobic. Implikasi dari hasil penelitian ini adalah kecenderungan untuk tidak bisa jauh dari gawai juga terlihat dari orang yang sehat sekalipun dan ini yang harus menjadi titik perhatian kita bersama terutama jika hal ini terjadi pada anak usia dini.

Dari beberapa hasil penelitian tersebut di atas menunjukkan bahwa faktor kognitif dan emosi juga tidak memberikan sumbangan yang besar dalam terbentuknya kecenderungan nomophobia. Artinya factor kognitif dan emosional atau afeksi sampai saat ini belum mampu digunakan sebagai tolok ukur dalam factor pembentuk kecenderungan nompphobia. Nomophobia mungkin saja terjadi disebabkan oleh faktor lain seperti faktor biologis, atau faktor behavioral. Penelitian yang dilakukan Sudarji (2017) dalam Wibowo (2020) dengan judul penelitian hubungan antara nomophobia dengan kepercayaan diri memperkuat dari penelitianpenelitian sebelumnya dimana tidak terdapat hubungan signifikan antara nomophobia dengan kepercayaan diri. Begitu pula dengan hasil penelitian ini menunjukkan bahwa tidak terdapat hubungan signifikan antara kecenderungan nomophobia terhadap perilaku sosial anak usia dini. Namun demikian kecenderungan sifat negative dari korelasi tersebut hendaknya menjadi perhatian bersama bagi kita semua untuk mencegah terjadinya perilaku nomophobia yang tentunya dalam jangka panjang akan berdampak buruk bagi perkembangan anak usia dini.

\section{SIMPULAN DAN SARAN}

Mengacu pada tujuan dari penelitian, beberapa simpulan yang dapat diambil yakni: (1) tidak terdapat perbedaan signifikan pada perilaku nomophobia anak usia baik di perdesaan maupun perkotaan. Kategori perilaku nomophobia di perdesaan dan perkotaan sebagian besar adalah kategori rendah. Tidak ada yang berkategori tinggi; (2) tidak terdapat perbedaan pada perilaku nomophobia pada anak usia dini berdasarkan jenis kelamin; (3) tidak terdapat perbedaan signifikan pada perilaku sosial anak usia baik di perdesaan maupun perkotaan. Kategori perilaku sosial di perdesaan dan perkotaan sebagian besar adalah kategori tinggi. Tidak ada yang berkategori rendah; (4) terdapat perbedaan signifikan (pada taraf nyata 90\%) pada perilaku sosial dimana skor rata-rata anak perempuan lebih tinggi daripada anak lakilaki; (5) tidak terdapat hubungan yang signifikan antara perilaku nomophobia dan perilaku sosial anak usia dini; (6) koefisien korelasi bersifat negatif yaitu $-0,085$ yang menunjukkan kecenderungan bahwa semakin tinggi perilaku nomophobia maka semakin rendah perilaku sosial anak usia dini.

\section{DAFTAR PUSTAKA}

Ehrenberg, A, Juckes, S, White, K.M. (2008). Personality and self-esteem as predictors of young people's technology use. Cyberpsychology \& Behavior, 11(6), 739-741.

Fachrizal, R. (2018). Inilah konten yang sering ditelusuri anak-anak Indonesia ketika online. Yogyakarta. http://e-journal.uajy.ac.id/478/1/0MM01549.pdf

Fauzi.A. (2013). Hubungan antara Keharmonisan Keluarga dan Dukungan Sosial Teman Sebaya dengan Perilaku Prososial Remaja di SMAN 2 Jombang.

Hasanah, U dan Martiastuti, K. (2018). Interaksi Keluarga: tinjauan teoritis dan aplikatif. Jakarta: Pustaka Karima

Hurlock, E.B. (2002). Psikologi perkembangan: suatu pendekatan sepanjang rentang kehidupan. Surabaya: Erlangga.

Indriyani, M \& Sofia, A. (2018). Persepsi orang tua terhadap gadget pada anak usia dini. Indonesian Journal of Early Childhood Issues, 1(1). 
Irmayanti, Y. (2018). Peran Orang Tua dalam Mendampingi Penggunaan Gawai pada Anak Usia Prasekolah. Universitas Muhammadiyah Surakarta

Istiana. (2018). Differences Youth Prosocial Behavior Viewed From Gender In Tanjung Rejo Medan Sunggal. Jurnal Diversita, 4(1).

King, ALS., Valenca, AM., Cardoso, A., Sancassiani, S. 2014. "Nomophobia”: Impact of Cell Phone Use Interfering with Symptoms and Emotions of Individuals with Panic Disorder Compares with a Control Group. Clinical Practice and Epidemiology in Mental Health, 10(1), 28-35

King, ALS., Valenca, AM., Nardi AE. 2010. Nomohobia: The mobile phone in panic disorder with agoraphobia reducing phobias or worsening of dependence?. Cognitive and Behavioral Neurology, 23(1), 52-54

King, ALS, Valença, AM, Silva, ACO. (2013) Nomophobia: Dependency on virtual environments or social phobia? Computers in Human Behavior 29(1), 140-144

Magdalena, K., Hasanah, U., Rusilanti. (2016). Perbandingan Sikap Agresivitas Remaja Pedesaan dan Perkotaan (Studi Kasus di Pedesaan Pandeglang Banten dan Perkotaan JakartaPusat). Jurnal Kesejahteraan Keluarga dan Pendidikan, 3(1). doi.org/10.21009/JKKP.031.09

Maulida, H. (2013). Menelisik Pengaruh Penggunaan Aplikasi Gadget Terhadap Perkembangan Psikologis Anak Usia Dini. Jurnal Ilmiah Teknologi Pendidikan. FKIP Universitas Negeri Semarang. Semarang

Rideout, V. (2013). Zero to eight: electronic media inthe lives of infants, toddlers and preschoolers. Common Sense Media Research Study

Sears, D. O., Johnathan, L. F., Anne, P. L. (1994). Psikologi Sosial Jilid 2. Alih Bahasa: Michael Adryanto. Jakarta: Erlangga

Susanto A. 2012. Perkembangan anak usia dini: pengantar dalam berbagai aspeknya. Jakarta: Kencana prenada media group

Tanjung, F. S., Huriyati, E., Ismail, D. (2017). Intensitas penggunaan gadget pada anak prasekolah yang kelebihan berat badan di Yogyakarta. Berita Kedokteran Masyarakat, 33(12).

Wibowo, G. A. (2020). Hubungan antara dukungan sosial dan nomophobia pada remaja. Universitas Islam Negri Sunan Ampel Surabaya

Yee, HK., Seok, CB., Hashmi, SI., Teng, TL., Indran, R. (2016). Why Gadget Usage Among Preschoolers Should Matter to Teachers? A Pilot Study. GESJ: Education Science and Psychology 2016 | No.3(40) ISSN 1512-1801

Yildirim, C., Sumuer E., Adnan M. (2015). A growing fear: Prevalence of nomophobia among Turkish college students. https://journals.sagepub.com/doi/10.1177/0266666915599025\#

Yildirim, C, Correia, A. P. (2015). Exploring the dimensions of nomophobia: Development and validation of a self-reported questionnaire. Computers in Human Behavior, 49, 130-137. 